\title{
Differences in Traffic Climate between Driving Simulation Scenarios with Different Complexity Levels
}

\author{
Yeşim Üzümcüoğlu ${ }^{1}$, İbrahim Öztürk² ${ }^{2}$, Türker Özkan ${ }^{3}$
}

Üzümcüoğlu, Y., Öztürk, İ., \& Özkan, T. (2020). Differences in traffic climate between driving simulation scenarios with different complexity levels. Nesne, 8(17), 171-179. DOI: 10.7816/nesne-08-17-01

\begin{abstract}
Keywords $\quad$ Road traffic injuries are one of the most important public health problems all over the world. Despite of the globality of the problem, driver behaviors, road traffic accidents and injuries show regional difference. Perceived traffic requirements, traffic climate is related to driver behaviors. In order to predict driver behaviors, Traffic Climate Scale is used, which climate, driving measures road users' perceptions towards traffic system. Previously, the validity of Traffic Climate Scale was tested simulator, road with self-report measures (i.e. Driver Behavior Questionnaire) and with simulator based results. Characteristics of safety simulator scenarios show differences based on purpose of research questions. However, researchers do not have enough information about whether participants perceive these differences or not. With respect to this, the aim of the present study is to test whether Traffic Climate Scale could be used to evaluate the characteristics of a simulated driving environment. For this reason, a total of 78 participants between the ages of 18 and $25(M=22.28, S D=1.64)$ drove two driving simulation scenarios. High complexity scenario was perceived as more internally demanding than low complexity scenario. The results showed that, in addition to the country-level measurement of traffic climate, traffic climate measurement might be used to evaluate the perception of driving simulation scenarios. There is also a need of future studies that includes different driving simulators and scenarios.
\end{abstract}

\section{Farkıı Karmaşıkık Seviyelerine Sahip Sürüş Simülasyon Senaryoları Arasında Trafik İklimine Bağlı Farklılıklar}

Öz

Anahtar kelimeler

İçsel ihtiyaçlar, trafik iklimi, sürüş simülatörü, yol

Trafik kazalarına bağlı yaralanmalar dünya çapında en önemli halk sağlığı problemlerinden biridir. Küresel bir problem olmasına rağmen, sürücü davranışları, traik kazaları ve yaralanmalar bölgesel farklılıklar göstermektedir. Algılanan trafik iklimi sürücü davranışları ile ilişkilidir. Sürücü davranışlarını yordamak için yol kullanııılarının trafik sistemine yönelik algılarını ölçen Trafik İklimi Ölçeği kullanılmaktadır. Daha önce Trafik İklimi Ölçeğinin geçerlik çalışmaları hem öz beyana dayanan ölçekler (Sürücü Davranışı Ölçeği) hem de simülatör kullanılan çalışmalar ile gerçekleştirilmiştir. Simülatör senaryolarının özellikleri, araştırma sorularının amacına göre farklılıklar gösterir. Ancak araştırmacılar, katılımcıların bu farklılıkları algılayıp algılamadığı hakkında yeterli bilgiye sahip değildir. Bu bağlamda, bu çalışmanın amacı Trafik İklimi Ölçeğinin simüle edilmiş bir sürüş ortamının özelliklerini değerlendirmek için kullanılıp kullanılamayacağını test etmektir. Bu çalışmanın amacı, sürüş simülatöründe trafik iklimi ölçümünün geçerliliğini test etmektir. Bu nedenle, iki sürüş simülasyonu senaryosu 18 ile 25 yaş arasındaki 78 katılımcı $(O r t=22.28, S S=1.64)$ tarafından tamamlanmıştır. Yüksek karmaşıklık senaryosu, düşük karmaşıklık senaryosundan içsel gereksinimler açısından daha yüksek olarak algılanmıştır. Sonuçlar, ülke genelinde trafik ikliminin ölçülmesine ek olarak, sürüş simülasyonu senaryolarının algılanmasını değerlendirmek için trafik iklimi ölçümünün kullanılabileceğini göstermiştir. Gelecekteki çalışmalarda farklı sürüş simülatörleri ve senaryoları ile yapılacak çalışmalara da gereksinim duyulmaktadır.

Article History

Arrived: October 2, 2019

Resived: June 30, 2020

Accepted: July 24, 2020
Author Note: We would like to thank the support from Turkish Academy of Sciences (i.e., TÜBA-GEBIP 400 Programme).

DOI: 10.7816/nesne-08-17-01

${ }_{1}^{1}$ Asst. Prof., TOBB University of Economics and Technology, Department of Psychology, ORCID: 0000-0002-4905-5518
${ }^{2}$ Research Asisstant, Middle East Technical University, Department of Psychology, ORCID: 0000-0002-5113-1225

${ }^{3}$ Professor, Middle East Technical University, Department of Psychology, ORCID: 0000-0002-5501-9257 
Injuries related to road traffic accidents can be considered as a global health problem since it causes more than 1.35 million people to loose their lives on the roads (WHO, 2018). Although road traffic injuries are a global problem, fatality and injury rates are higher in low and middle-income countries (WHO, 2018). Similarly, driver behaviors also show differences across countries (e.g. Lajunen, Parker, \& Summala, 2004; Özkan, Lajunen, Chliaoutakis, Parker, \& Summala, 2006; Warner, Özkan, Lajunen, \& Tzamalouka, 2011). It is assumed that, one of the underlying reasons of differences among countries might be perceived traffic climate since it is related to driver behaviors (e.g. Chu, Wu, Atombo, Zhang, \& Özkan, 2019; Gehlert, Hagemeister, \& Özkan, 2014; Üzümcüoğlu, Özkan, Wu, \& Zhang, 2019; Zhang, Ge, Qu, Zhang, \& Sun, 2018).

Traffic climate is described as "the road users' (e.g., drivers') attitudes and perceptions of the traffic in a context (e.g., country) at a given point in time" (Özkan \& Lajunen, 2011). Gehlert et al. (2014) defined traffic climate as "as a function of a person being able to master a situation given its perceived properties and dynamic aspects as well as his/her own capabilities". Traffic climate is mainly investigated under three dimensions: external affective demands, functionality, and internal requirements. External affective demands dimension is about circumstances that cause emotional engagement in traffic environments, such as exciting and fast. Functionality dimension is about characteristics of a functional traffic system, which are about preventive measures, enforcements and being free-flowing. Internal requirements include knowledge, skills and abilities that are required in traffic, such as requiring patience, skills, experience and cautiousness.

In the literature, studies showed that perceived traffic climate is related with driver behaviors (e.g. $\mathrm{Chu}, \mathrm{Wu}$, Atombo, Zhang, \& Özkan, 2019; Gehlert, Hagemeister, \& Özkan, 2014; Üzümcüoğlu et al., 2019; Zhang, Ge, Qu, Zhang, \& Sun, 2018). Driver behaviors are usually examined based on theoretical taxonomy of aberrant driver behaviors that includes errors and violations (Reason, Manstead, Stradling, Baxter, \& Campbell, 1990). The relationships between traffic climate and driver behaviors show both similar and different patterns among countries. To illustrate, in China, less internal requirements and higher external affective demands were related with higher violations and errors (Chu et al., 2019). The same relationship for violations was also reported for Turkey (Üzümcüoğlu et al., 2019) and Germany (Gehlert et al., 2014). The different patterns were mainly reported for the functionality dimension. In Turkey and China, as drivers perceived traffic climate more functional, they reported lower numbers of violations (Chu et al., 2019; Üzümcüoğlu et al., 2019); whereas higher functionality was related to higher violations in German sample (Gehlert et al., 2014).

Driving simulators are one of the experimental methods used to examine human factors in driving with various features. There are different driving simulators with various features such as one or more screens, type of vehicle controls and sound systems (Carsten \& Jamson, 2011). As discussed by Calvi, Benedetto and de Blasiis (2012), the characteristics of the driving scenarios affect driving performance. In another study, Ronen and Yair (2013) investigated how adaptation time to the driving environment changes in roads with different levels of complexity as curved, urban and straight roads. It was found that roads with different levels of complexity require different adaptation periods. Moreover, curved road was evaluated as the most demanding followed by urban road and straight road.

Based on the related literature, driver behaviors are related to the way that drivers perceive the traffic climate. Traffic Climate Scale is a reliable and valid instrument to examine the characteristics of a 
given country's traffic system. Previously, the validity of Traffic Climate Scale was tested with self-report measures (i.e. Driver Behavior Questionnaire) and with simulator based results. Characteristics of simulator scenarios show differences based on purpose of research questions. However, researchers do not have enough information about whether participants perceive these differences or not. With respect to this, the aim of the present study is to test whether Traffic Climate Scale could be used to evaluate the characteristics of a simulated driving environment.

\section{Method}

\section{Participants}

A total number of 80 young drivers (40 male and 40 female) participated in the study. One male driver and one female driver were excluded from the further analysis due to being outliers in terms of lifetime kilometres driven. Analyses were conducted with 78 participants (39 male and 39 female) with a valid Turkish type B driving license. The ages of participants were ranged between 19 and $25(M=22.28$, $S D=1.64)$. Lifetime kilometers driven were ranged between $3750 \mathrm{~km}$ to $200000 \mathrm{~km}(M=33867.11, S D=$ $35116.81)$.

\section{Measures}

Demographic Information Form: Demographic information form was used to collect personal and drivingrelated information. Personal demographic questions were related to age and gender of the participants. Driving-related questions were relevant to driving history such as lifetime kilometres driven by the drivers.

Traffic Climate Scale: Traffic Climate Scale is developed by Özkan and Lajunen (unpublished) for the measurement of the perception of traffic system by road users. The scale consists of 44 items in 6-point Likert-type from 1 (does not describe it at all) to 6 (describes it fully) with three dimensions; external affective demands, functionality and internal requirements. The factor structure of the scale was used as described in Üzümcüoğlu Zihni (2018). External affective demands (EAD) consisted of 5 items, functionality (FUN) consisted of 13 items, and internal requirements (INT) consisted of 22 items. In the current study, participants were asked to evaluate the driving simulation. The Cronbach's alpha reliabilities of the dimensions for high complexity driving scenario were $.74, .86, .93$ and low complexity driving scenario were $.82, .84$, and .92 , respectively.

Driving Simulation: For the driving simulation, STISIM Drive M100W (STISIM Drive ${ }^{\circledR}$ Model 100 Wide Field-of-View Complete System) with the software of STISIM DRIVEM100W-ASPT driving simulator was used. The driving simulator consists of three screens and game-type driving controls (see Figure 1.). Three different driving scenarios; one training and two experiment scenarios were used. Driving scenarios were characterized as high complexity and low complexity.

Training Scenario: The training scenario was used to introduce the driving simulation and to test whether participants experienced any symptoms of motion sickness or not. The test scenario was in manual transmission mode and three kilometers long. The road consisted of four lanes, two lanes on each side, and included five traffic lights with light traffic. 


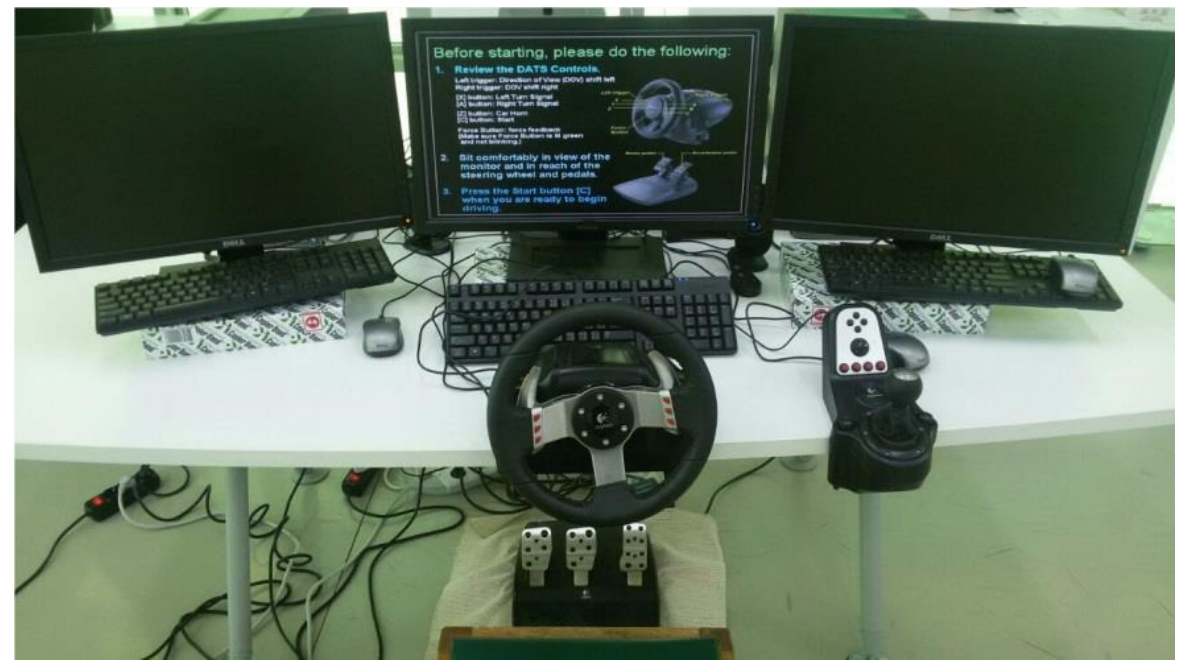

Figure 1. The Driving Simulator Used in the Current Study

High Complexity Driving Scenario: In the high complexity driving (HC), the scenario was displayed through three screens and was controlled by using manual transmission (see Figure 2.). The scenario was nine kilometers long and three different roadways, an urban road with horizontal curves, inter-urban highway with no horizontal curves and countryside road with horizontal curves were used. The urban road consisted of four lanes with parked cars and ongoing traffic. The inter-urban road consisted of six lanes with traffic on both sides. The countryside road consisted of two lanes with traffic on both sides. There were also certain events such as a parked car entering the road and pedestrians suddenly jumping into the road.

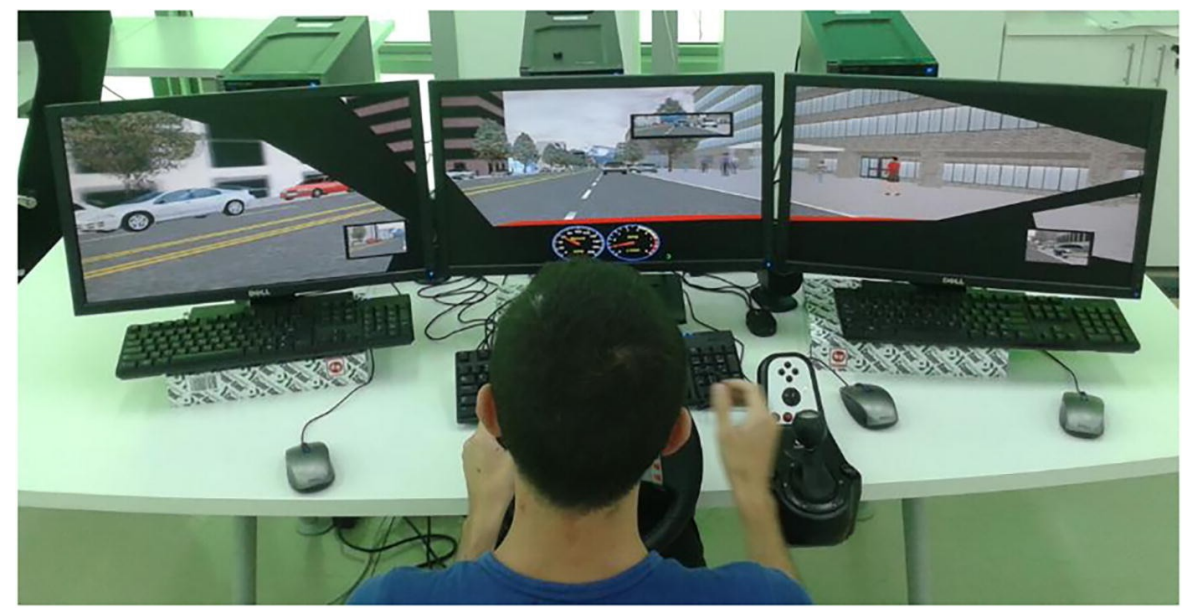

Figure 2. The Driving Simulator Used in the Current Study - High Complexity

Low Complexity Driving Scenario: In the low complexity driving (LC), the scenario was displayed through one, center, screen and was controlled by using automatic transmission (see Figure 3.). The scenario was 10 kilometers long and three different roadways urban road, rural road and countryside road with horizontal curves were used. The urban road included parked cars and oncoming traffic. The rural road included oncoming traffic and forest like side view. Finally, the countryside road consisted of two lanes with traffic 
on both sides. There were not any events such as suddenly moving cars as in HC scenario in LC scenario. The comparison of HC and LC Scenarios were presented in Table 1.

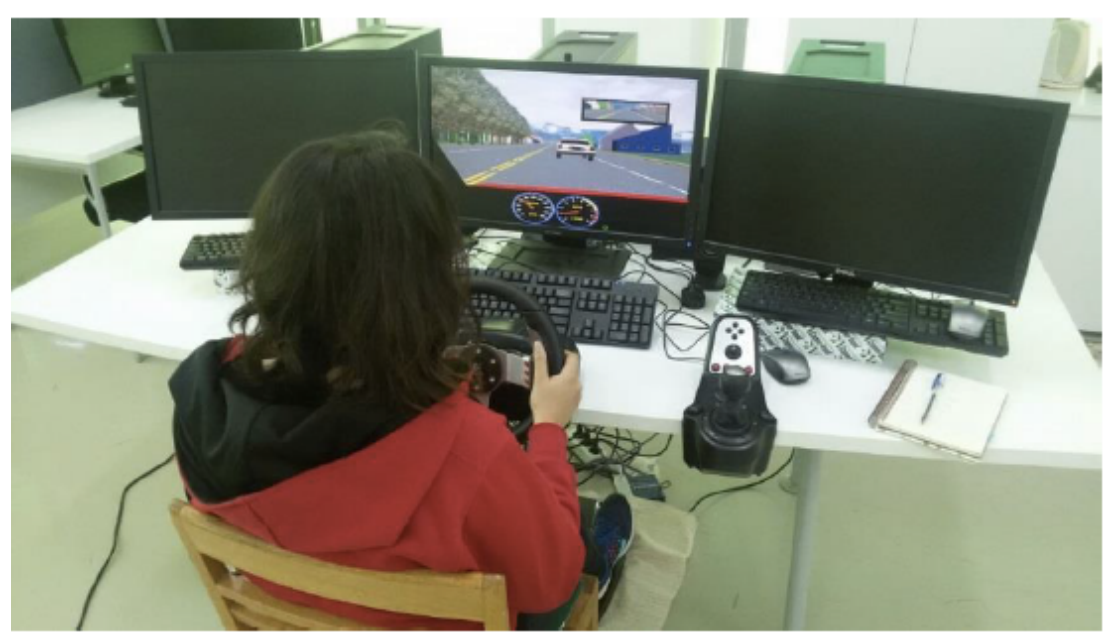

Figure 3. The Driving Simulator Used in the Current Study - Low Complexity

Table 1

Comparison of High and Low Complexity Scenarios

\begin{tabular}{|c|c|}
\hline High Complexity Scenario & Low Complexity Scenario \\
\hline 1. Three screens & 1. One screen \\
\hline 2. Manual transmission & 2. Automatic transmission \\
\hline 3. Nine kilometers & 3. Ten kilometers \\
\hline 4. Three different road ways: & 4. Three different roadways: \\
\hline i. urban road with horizontal curves & i.urban road \\
\hline ii. inter-urban highway & ii. rural road \\
\hline iii. countryside road with horizontal curves & iii.countryside road with horizontal curves \\
\hline 5. The urban road: four lanes with parked cars and ongoing traffic & 5. The urban road: parked cars and oncoming traffic \\
\hline 6. The inter-urban: six lanes with traffic on both sides & 6. The rural road: oncoming traffic and forest like side view \\
\hline 7. The countryside road: two lanes with traffic on both sides & 7. The countryside road: two lanes with traffic on both sides \\
\hline $\begin{array}{l}\text { 8. Certain events such as a parked car entering the road and } \\
\text { pedestrians suddenly jumping into the road }\end{array}$ & $\begin{array}{l}\text { 8. No events such as suddenly moving cars as in } \mathrm{HC} \text { scenario } \\
\text { in LC scenario. }\end{array}$ \\
\hline
\end{tabular}

\section{Procedure}

After getting ethical approval from Middle East Technical University Applied Ethics Research Center, the study was announced. Snowball and convenience sampling were used to reach out to the participants. The study was conducted in ODTÜ-TSK MODSIMMER Building, Human Factors Laboratory. Participants, firstly, got informed consent. After that, they drove the training scenario. None of the participants experienced any symptoms of motion sickness. After the training scenario, participants first drove high complexity driving scenario and filled out Traffic Climate Scale for that driving scenario. After the HC scenario, they drove low complexity scenario and filled out Traffic Climate Scale for that driving scenario. After completing all the measurements, participants got debriefing form and paid with 20 dollars for their participation. The whole procedure took approximately 2 hour and data were collected as a part of a big project. 


\section{Results}

\section{Correlation Analyses}

The correlations among the study variables, namely age, gender, lifetime kilometer, external affective demands, functionality and internal requirements for scenario 1 and scenario 2 and the internal reliability coefficients (i.e. Cronbach's Alpha) of subscales for Scenario HC and Scenario LC were presented in Table 2.

Table 2

Correlations among Study Variables

\begin{tabular}{llllllllllllll}
\hline $\begin{array}{l}\text { High } \\
\text { Complexity }\end{array}$ & 1 & 2 & 3 & 4 & 5 & 6 & $\begin{array}{l}\text { Low } \\
\text { Complexity }\end{array}$ & 1 & 2 & 3 & 4 & 5 & 6 \\
\hline 1. Age & 1 & & & & & & 1. Age & 1 & & & & \\
2. Gender & .10 & 1 & & & & & 2. Gender & .10 & 1 & & & \\
3. Total Km & $.33^{* *}$ & -.22 & 1 & & & & 3. Total Km & $.33^{* *}$ & -.22 & 1 & & & \\
4. EAD_HC & -.16 & -.11 & .03 & 1 & & & 4. EAD_LC & -.22 & .02 & -.01 & 1 & & \\
5. Func_HC & -.13 & -.09 & -.10 & $.27^{*}$ & 1 & & 5. Func_LC & -.19 & -.08 & -.15 & .09 & 1 & \\
6. IR_HC & -.03 & .11 & .01 & $.31^{*}$ & $-.40^{* *}$ & 1 & 6. IR_LC & $-.29^{*}$ & .16 & -.03 & $.65^{* *}$ & -.02 & 1 \\
Cronbach Alpha & & & & .74 & .86 & .93 & Cronbach Alpha & & & & .82 & .84 & .92
\end{tabular}

Note: EAD: External Affective Demands; Func: Functionality; IR: Internal Requirements; HC: High Complexity; LC: Low Complexity; *<p.05; $* * \mathrm{p}<.01$.

Age was positively correlated with total kilometer $(r=.33, p=.003)$ and negatively correlated with internal requirements in Scenario LC $(r=-.29, p=.011)$. In Scenario LC, external affective demands dimension was positively related to internal requirements $(r=.65, p<.001)$. In Scenario HC, external affective demands were positively related to functionality $(r=.27, p=.016)$ and internal requirements $(r=$ $.31, p=.006)$. Functionality was negatively related to internal requirements $(r=-.40, p<.001)$.

\section{Comparison Analyses}

To compare the traffic climate difference between $\mathrm{HC}$ and LC, paired sample t-test analyses were conducted (See Table 3). There was a significant difference between Scenario HC and LC in internal requirements dimension $(t(76)=3.417, p=.001)$. Drivers perceived Scenario HC $(M=3.87, S D=.84)$ more internally demanding than Scenario LC $(M=3.53, S D=.77,95 \%$ CI $[.14, .55])$.

Table 3

Comparison between Scenario HC and LC

\begin{tabular}{llllll}
\hline & & Mean & $S D$ & $t$ & $p$ \\
\hline EAD & & & & 1.393 & .168 \\
& HC & 3.69 & .97 & & .617 \\
Func & LC & 3.49 & 1.01 & -.502 & \\
& & & & & .001 \\
\multirow{4}{*}{ IR } & HC & 3.68 & .84 & 3.417 & \\
& LC & 3.72 & .78 & & \\
& & & & & \\
& HC & 3.87 & .84 & & \\
\hline
\end{tabular}




\section{Discussion}

The aim of the present study was to test whether Traffic Climate Scale could be used to evaluate the characteristics of a simulated driving environment. In line with this aim, two different driving scenarios were developed with different complexity levels (i.e. high and low complexity). The results suggested that, the participants perceived HC scenario more internally demanding than LC scenario. In other words, drivers perceived scenario with HC more cognitively demanding and requiring higher skills than scenario with LC. In the current study two scenarios had some basic technical structural differences. To illustrate, the high complexity scenario used three screens, manual transmission and had more events whereas the low complexity scenario was in automatic transmission with one screen and involved fewer events. Due to these differences, as expected, drivers evaluated the high complexity scenario as more internally demanding than low complexity scenario.

Before the comparison analyses, the relationships between the factors of traffic climate were analyzed for each scenario separately. In the high complexity scenario, external affective demands were positively related to functionality and internal requirements. Functionality was negatively related to internal requirements. In the low complexity scenario, only external affective demands were positively related to internal requirements. Taken together the correlations in two scenarios, it might be suggested that, as the complexity of scenario increases, drivers' perceptions towards features of traffic environment might also increase.

According to the Risk Homeostasis Theory, a person has a perceived certain level of risk in an action. If the perceived risk decreases in one area, the person will engage in risk-taking behavior in the same area or in another area (Wilde, 1982). So, a driver has an acceptable level of risk and they re-arrange their behaviors based on this acceptance level. To illustrate for road safety, when a driver is asked to wear seat belt, they might engage in risk behaviors, such as speeding, overtake more dangerously (Malnaca, 2008). It might be suggested that, when a driver drives in a low complex traffic environment, they might perceive it as less risky, which may cause driver to engage in secondary tasks (e.g. phone use) rather than focusing on traffic environment. Rudin-Brown, Edquist, and Lenné (2014) suggested that higher complexity of a road was related with lower speed. The findings also showed that, on roads with higher complexity, drivers pay more attention on peripheral detection task, which is also about attention. Taken together, it might be plausible to infer that, roads with higher complexity might be helpful to keep drivers attention on road environment.

The result of the current study showed that different driving scenarios were evaluated differently in terms of internal requirements rather than external affective demands and functionality. External affective demands and functionality dimensions of the traffic climate by definition are related to the outside environment. On the other hand, internal requirements are the reflection of characteristics of the outside environment as evaluated by the drivers' own skills. In other words, driver might evaluate the required skills and cognitive demands in a traffic environment based on their own skills. With respect to this, it might be possible to explain that drivers evaluate simulator scenarios based on their own skills, since outside environment might not be reflected as concrete enough since it is a virtual environment. As discussed by Van Huysduynen, Terken and Eggen (2018), driving simulators represent certain limitations. For example, fixed based driving simulators like the one used in the present study, do not provide feedback to the driver 
about acceleration and deceleration and were evaluated as less realistic, which might be about the participants' evaluations based on their own skills rather than the outside environment.

The studies in literature highlight the relationship between traffic climate and driver behaviors and also indicate that the measurement of traffic climate might be used to successfully evaluate the driving environment for a certain country (Gehlert et al., 2014; Zhang et al., 2018). In line with these findings, the results of the current study show that traffic climate of a simulated driving environment might be also evaluated by using self-report measures. In terms of the dimensions of the traffic climate, it has been found that only internal requirements were significantly different between two experimentally manipulated driving environments. As discussed earlier, due to lack of feedback, drivers might be evaluating the driving simulation as a measurement of driving performance by focusing on their skills. Based on the results, it might be plausible to suggest that, TCS can be used as an effective tool to investigate whether the scenario is cognitively demanding or not. To the authors' knowledge, the current study is the first one of its kind that assessed the driving simulator scenarios based on traffic climate. In future studies, the role of traffic climate in comparing scenarios can be investigated by comparing data received from simulators with higher capacities.

In the current study, drivers did not have any enforcement (e.g. tickets or feedback) for the rules that they violated during driving. It is plausible to suggest that, lack of ticket or feedback for violations might be a possible limitation for the non-significant results for functionality dimension. In addition, external affective demands dimension is about situations that cause emotional engagement in traffic environments. However results showed that, in both scenarios, the focus was on the complexity level of roads rather than interaction with other road users. Hence, in future studies, new scenarios might be developed with instant feedback systems to test the differences for functionality. In addition, interactions with other road users might be included (e.g. pedestrians crossing the road) to test how these interactions affect drivers' perceptions about emotional engagement.

\section{References}

Calvi, A., Benedetto, A., \& De Blasiis, M. R. (2012). A driving simulator study of driver performance on deceleration lanes. Accident Analysis \& Prevention, 45, 195-203.

Carsten, O., \& Jamson, A. H. (2011). Driving simulators as research tools in traffic psychology. In Handbook of Traffic Psychology (pp. 87-96). Academic Press.

Chu, W., Wu, C., Atombo, C., Zhang, H., \& Özkan, T. (2019). Traffic climate, driver behaviour, and accidents involvement in China.Accident Analysis \& Prevention, 122, 119-126.

Gehlert, T., Hagemeister, C., \& Özkan, T. (2014). Traffic safety climate attitudes of road users in Germany. Transportation Research Part F: Traffic Psychology and Behaviour, 26, 326-336.

Lajunen, T., Parker, D., \& Summala, H. (2004). The Manchester Driver Behaviour Questionnaire: A crosscultural study. Accident Analysis\&Prevention, 36(2), 231-238.

Malnaca, K. (2008). Risk homeostasis theory in traffic safety. In Proceedings of the 21th ICTCT Workshop.

Özkan, T., \& Lajunen, T. (2011). Person and environment: Traffic culture. Handbook of Traffic Psychology, 179-192. 
Özkan, T., Lajunen, T., Chliaoutakis, J., Parker, D., \& Summala, H. (2006). Cross-cultural differences in driving behaviours: A comparison of six countries. Transportation Research Part F: Traffic Psychology and Behaviour, 9, 227-242.

Reason, J., Manstead, A., Stradling, S., Baxter, J., \& Campbell, K. (1990). Errors and violations on the roads: a real distinction?. Ergonomics, 33(10-11), 1315-1332.

Ronen, A., \& Yair, N. (2013). The adaptation period to a driving simulator. Transportation Research Part F: Traffic Psychology and Behaviour, 18, 94-106.

Rudin-Brown, C. M., Edquist, J., \& Lenné, M. G. (2014). Effects of driving experience and sensationseeking on drivers' adaptation to road environment complexity. Safety Science, 62, 121-129.

Üzümcüoğlu, Y., Özkan, T., Wu, C., \& Zhang, H. (2019). How drivers perceive traffic? How they behave in traffic of Turkey and China?. Transportation research part F: traffic psychology and behaviour, 64, 463-471.

Üzümcüoğlu-Zihni, Y. (2018). The Relationship Between Traffic Climate And Driver Behaviors: Explicit And Implicit Measures With Turkish And Chinese Samples(Doctoral Dissertation, Middle East Technical University).

Warner, H. W., Özkan, T., Lajunen, T., \& Tzamalouka, G. (2011). Cross-cultural comparison of drivers' tendency to commit different aberrant driving behaviours. Transportation Research Part F: Traffic Psychology and Behaviour, 14(5), 390-399.

Wilde, G. J. (1982). The theory of risk homeostasis: implications for safety and health. Risk Analysis, 2(4), 209-225.

World Health Organization. (2018). Global status report on road safety 2018. Retrieved from https://apps.who.int/iris/bitstream/handle/10665/276462/9789241565684-eng.pdf

Zhang, Q., Ge, Y., Qu, W., Zhang, K., \& Sun, X. (2018). The traffic climate in China: The mediating effect of traffic safety climate between personality and dangerous driving behavior. Accident Analysis \& Prevention, 113, 213-223. 